Article

\title{
Temperature Changes and SEM Effects of Three Different Implants-Abutment Connection during Debridement with Er:YAG Laser: An Ex Vivo Study
}

\author{
Jacek Matys ${ }^{1,2, *(\mathbb{D})}$, Umberto Romeo ${ }^{3}$, Krzysztof Mroczka ${ }^{4}$, Kinga Grzech-Leśniak ${ }^{1,5}$ (D) \\ and Marzena Dominiak ${ }^{1}$ \\ 1 Dental Surgery Department, Medical University, 50-425 Wroclaw, Poland; kgl@periocare.pl (K.G.-L.); \\ marzena.dominiak@wp.pl (M.D.) \\ 2 Private Dental Practice, Lipowa 18, 67-400 Wschowa, Poland \\ 3 Department of Oral Sciences and Maxillofacial Surgery, 00161 Rome, Italy; umberto.romeo@uniroma1.it \\ 4 Institute of Technology, Pedagogical University, 30-084 Krakow, Poland; krzysztof.mroczka@up.krakow.pl \\ 5 Department of Periodontics, School of Dentistry, Virginia Commonwealth University, \\ Richmond, VA 23298, USA \\ * Correspondence: jacek.matys@wp.pl; Tel.: +48-791511789; Fax: +48-717840253
}

Received: 29 October 2019; Accepted: 12 November 2019; Published: 14 November 2019

\begin{abstract}
The study aimed to evaluate a temperature increase in, and damage to, titanium implants during flapless laser debridement. The study analyzed 15 implants with various implant-abutment connections: a two-piece implant $(\mathrm{n}=4)$ with a screw abutment (IA-Implant-Abutment) and a one-piece implant with a ball type fixture $(\mathrm{BTF}, \mathrm{n}=4)$ or fix type fixture $(\mathrm{FTF}, \mathrm{n}=4)$. The implants were placed in porcine mandibles $2 \mathrm{~mm}$ over a bone crest to imitate a peri-implantitis. The implants were debrided in contact mode for $60 \mathrm{~s}$ with a Er:YAG laser at fluence of $9.95 \mathrm{~J} / \mathrm{cm}^{2}$ (G1 group: $50 \mathrm{~mJ} / 30 \mathrm{~Hz}$ ); $19.89 \mathrm{~J} / \mathrm{cm}^{2}$ (G2 group: $100 \mathrm{~mJ} / 30 \mathrm{~Hz}$ ); $39.79 \mathrm{~J} / \mathrm{cm}^{2}$ (G3 group: $200 \mathrm{~mJ} / 30 \mathrm{~Hz}$ ), or a scaler with a ceramic tip (G4 control group: $4 \mathrm{~W} / 20 \mathrm{~Hz}$ ). The temperature was measured with thermocouples at implant and abutment levels. The damage in the titanium surface $(n=3$, non-irradiated implants from each type) was assessed using SEM (Scanning Electron Microscopy). The temperature increase at the implant level for the laser was higher at IA in contrast with FTF and BTF. $(p<0.05)$ The temperature change at the abutment level was lower for the scaler in contrast to Er:YAG laser at FTF. ( $p<0.0002)$ Er:YAG laser didn't increase the temperature by $10^{\circ} \mathrm{C}$ at $100 \mathrm{~mJ} / 30 \mathrm{~Hz}$ and $50 \mathrm{~mJ} / 30 \mathrm{~Hz}$. Based on SEM analysis, cracks occurred on the surface of two-piece implants and were more pronounced. Cracks and the melting of the titanium surface of two-piece implants cleaned with Er:YAG laser at 100 or $200 \mathrm{~mJ}$ were observed. The specimens treated with the ultrasonic scaler with a plastic curette showed the remaining dark debris on the titanium surface. We recommend using Er:YAG laser at $50 \mathrm{~mJ} / 30 \mathrm{~Hz}$ during flapless implants debridement.
\end{abstract}

Keywords: one-piece implant; peri-implantitis; peri-mucositis; titanium; two-piece implant

\section{Introduction}

Rehabilitation of patients needing dental implant restorations is now a predictable method of treatment; however, failures occur [1]. Bacterial infection of dental implants is the most common reason for peri-implant mucositis or peri-implantitis, and causes implant loss [2-4].

Peri-implantitis and peri-implant mucositis are connected with a bacterial biofilm occurrence, which is composed mainly of gram-positive facultative cocci and rods bacteria [5-7]. The inflammation process around an implant surface needs to be removed, because it leads to crestal bone loss and decreases in long-term implant survival rate. Decontamination of infected titanium implant surface 
and removal of bacterial biofilm can be achieved by surgical and nonsurgical means [8]. Surgical therapy involves resective or regenerative techniques for advanced peri-implantitis in shallow or deep intrabony defects, respectively $[9,10]$. Furthermore, in early and moderate stages of peri-implantitis, nonsurgical techniques, e.g., air-powder abrasion, citric-acid, chlorhexidine application, ultrasonic, manual debridement, implantoplasty or laser treatment, can be applied [11-20]. However, the complex architecture of the implant makes establishing a decontamination protocol difficult. Thus, traditional tools such as curettes or ultrasonic scalers used alone are inadequate to ensure proper treatment of an implant surface contaminated with bacterial biofilm [21]. Moreover, mechanical debridement of the titanium surface carries the potential risk of damage to the implant surface [22-24].

A useful tool for nonsurgical implant surface debridement and detoxification are erbium lasers [13]. Recent studies showed the benefits of Er:YAG laser use operating in a non-contact mode for soft tissues $[25,26]$, for bone $[27,28]$ and especially for bacterial biofilm eradication [29] without damage [30] to the dental implant titanium surface or overheating of peri-implant tissue. Additionally, a laser beam allows for the cleaning of even a small area of the implant threads which are inaccessible to mechanical instruments [31]. Therefore, our previously published study [18] showed differentiation in temperature increase for the two most common titanium grades used in implant dentistry when irradiating with a diode and Er:YAG lasers. We noted that implants composed of grade IV titanium heat up much faster than grade $\mathrm{V}$ titanium implants composed of titanium, aluminum, and vanadium alloy. Moreover, an analysis of implant temperature increase concerning implant diameter revealed significant differences between both laser types in terms of a correlation between a rise in temperature and a decrease in implant diameter. Thus, in this study, we compared the temperature gradient after laser debridement for various implant to abutment connection types at the same implant titanium grade.

It was proven that Er:YAG lasers could play a significant role in decontaminating an infected implant surface [32]. However, particular attention should be paid to prevent overheating of the bone and damage to implant surface when using these devices during surgery [33]. Due to direct bone-implant-contact and the unique composition of the soft tissue in the implant neck area, the blood flow in this area is reduced, which increases the risk of thermal injuries being transmitted by the implant to the bone tissue. Eriksson et al. [34,35] found in a series of studies that increasing the temperature of bone tissue by $10^{\circ} \mathrm{C}$ for $60 \mathrm{~s}$ causes permanent changes in the bone structure. Therefore, a tissue temperature gradient $(\Delta \mathrm{Ta})$ below $10^{\circ} \mathrm{C}$ should be regarded as optimal and safe.

Our study aimed to evaluate the implant temperature increase, depending on the type of implant-to-abutment connection and various laser parameters, during implants' debridement using Er:YAG laser and ultrasonic scaler in nonsurgical approaches. Furthermore, damage to the implant titanium surface was analyzed.

\section{Materials and Methods}

\subsection{Samples Collection}

Twelve heads of a 10-month-old male pigs, breed: Złotnicka Biała, intended for consumption, and which had been obtained from a butcher, were used in this study. We applied two different devices: an Er:YAG laser (LightTouch, Syneron, Yokneam, Israel) and an ultrasonic scaler with a plastic tip (PM200, EMS, Nyon, Switzerland) for the debridement of three various implant types ( $n=15)$; a two-piece implant with a screw-type implant-to-abutment connection (IA, $n=5)$ (Slimline, Dentium Co., Seoul, Korea), and two types of one-piece implant with a ball type fixture (BTF, $n=5)$ and a fix type fixture $($ FTF, $\mathrm{n}=5$ ) (Slimline, Dentium Co., Seoul, Korea) (Figure 1). 


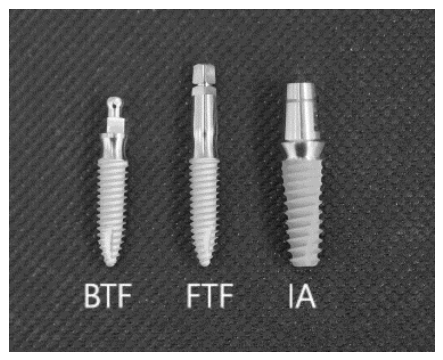

Figure 1. Type of grade 4 titanium alloys implants used in the study (BTF—ball type fixture; FTF-fix type fixture; IA-implant-to-abutment connection of two-piece implants).

\subsection{Sample Preparation}

Twelve mandibles $(n=12)$ were prepared from the pig heads, then washed under tap water and left for $4 \mathrm{~h}$ before the research was commenced. In every mandible, preparation of the soft tissues between the canine (C) and first premolar (P1) gave access to the mandibular alveolar ridge. Ethical approval was not required for this animal ex-vivo study.

\subsection{Surgical Procedure}

In the study area of the mandible, a full-thickness flap had been made by two vertical and one horizontal cuts using a $15 \mathrm{C}$ scalpel blade. The soft tissue flap was detached, and using drills, three various implant beds with a length of $12 \mathrm{~mm}$ were prepared, according to manufacturer protocol. A hole ( $3 \mathrm{~mm}$ in diameter) was drilled in each mandible at mid-height of the buccal side of the implant bed, with a trephine bur to place a K Thermocouple Probe 1 (P1), type TP-02 (Zhangzhou Weihua Electronic Co., Zhangzhou, China). In each implant bed, a corresponding implant composed of grade IV pure titanium was placed: a two-piece implant (diameter of $3.6 \mathrm{~mm}$ ) with standard straight screw abutment (IA), a one-piece implant (diameter of $3.0 \mathrm{~mm}$ ) with BTF or a one-piece implant (diameter of $3.0 \mathrm{~mm}$ ) with FTF. The implants with abutments were placed in porcine mandibles of $2 \mathrm{~mm}$ over a bone crest to imitate a periimplantitis. The abutments were exposed through small cuts in the soft tissue, and the flap was then repositioned and sutured to the soft tissue using non-absorbable suture (Dafilon ${ }^{\circledR}$, Braun, Germany). The second, a K Thermocouple Probe 2 (P2), type TP-02 (Zhangzhou Weihua Electronic Co.), was attached to the border of the implant and abutment. Debridement procedure was performed by placing the laser or scaler tip in a pocket, $2 \mathrm{~mm}$ below soft tissue margin, and moving the tip up and down from the medial to the distal implant/abutment area for $60 \mathrm{~s}$ (Figures 2 and 3).
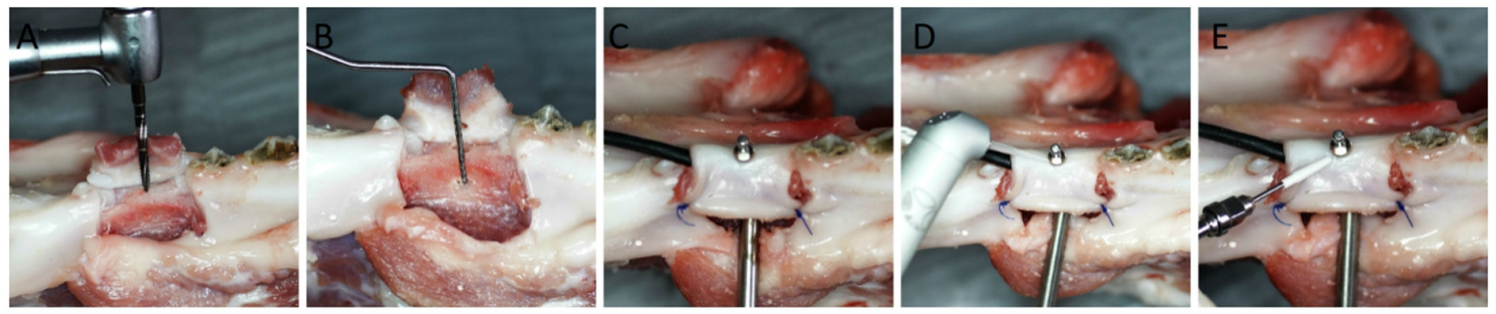

Figure 2. Surgical and measurement procedures used in the study. (A) The implant bed preparation. (B) Prepared implant bed and a hole with a diameter of $3 \mathrm{~mm}$ at mid-height of the buccal side of the implant bed for a Thermocouple Probe placement. (C) The implant, with two probes placed at mid-height and collar level of the implant. (D) Er:YAG laser with a sapphire tip before debridement procedure. (E) The scaler with a plastic tip before debridement procedure. 


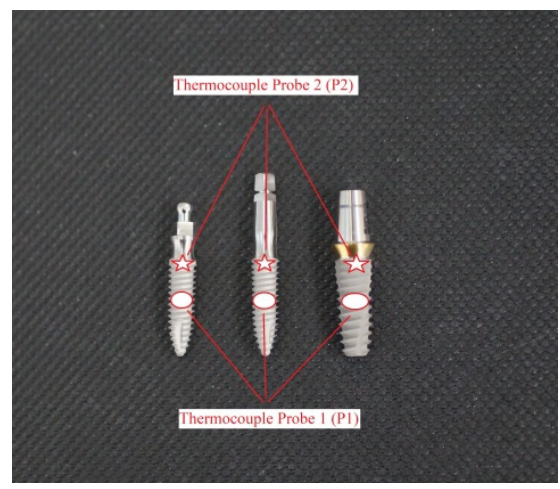

Figure 3. The position of the thermocouples P1 (red ellipse) and P2 (red arrow) attached to the implant surface.

\subsection{Study Groups}

The study specimens $(n=12)$ were divided into four groups: G1 $(n=3), G 2(n=3), G 3(n=3), G 4$ $(n=3)$.

G1 Group: Er:YAG laser (LiteTouch ${ }^{\circledR}$, Syneron Dental, Yokneam, Israel), operation mode for hard tissues (HT) was used, power: $50 \mathrm{~mJ}$, frequency: $30 \mathrm{~Hz}$, energy density per pulse: $9.95 \mathrm{~J} / \mathrm{cm}^{2}$, water spray cooling (100\%): $30 \mathrm{~mL} / \mathrm{min}$., size of the tip: $0.8 \mathrm{~mm} \times 17 \mathrm{~mm}$, distance: contact mode.

G2 Group: Er:YAG laser (LiteTouch ${ }^{\circledR}$, Syneron Dental), operation mode for hard tissues (HT) was used, power: $100 \mathrm{~mJ}$, frequency: $30 \mathrm{~Hz}$, energy density per pulse: $19.89 \mathrm{~J} / \mathrm{cm}^{2}$, water spray cooling (100\%): $30 \mathrm{~mL} / \mathrm{min}$., size of the tip: $0.8 \mathrm{~mm} \times 17 \mathrm{~mm}$, distance: contact mode.

G3 Group: Er:YAG laser (LiteTouch ${ }^{\circledR}$, Syneron Dental), operation mode for hard tissues (HT) was used, power: $200 \mathrm{~mJ}$, frequency: $30 \mathrm{~Hz}$, energy density per pulse: $39.79 \mathrm{~J} / \mathrm{cm}^{2}$, water spray cooling (100\%): $30 \mathrm{~mL} / \mathrm{min}$., size of the tip: $0.8 \mathrm{~mm} \times 17 \mathrm{~mm}$, distance: contact mode.

G4 group (control): ultrasonic scaler (PM200, EMS, Nyon, Switzerland with a plastic tip at $4 \mathrm{~W} / 20 \mathrm{~Hz}$.), power: $4 \mathrm{~W}$, frequency: $20 \mathrm{~Hz}$, water spray cooling: $30 \mathrm{~mL} / \mathrm{min}$ (Table 1).

Table 1. The parameters of devices used in the study.

\begin{tabular}{|c|c|c|c|c|c|c|c|c|c|c|}
\hline $\begin{array}{l}\text { Study } \\
\text { Groups }\end{array}$ & Handpiece & $\begin{array}{l}\text { Distance } \\
(\mathrm{mm})\end{array}$ & $\begin{array}{c}\text { Energy } \\
(\mathrm{mJ})\end{array}$ & $\begin{array}{c}\text { Frequency } \\
\text { (Hz) }\end{array}$ & $\begin{array}{c}\text { Power } \\
\text { (W) }\end{array}$ & $\begin{array}{l}\text { Spot } \\
(\mathrm{mm})\end{array}$ & $\begin{array}{c}\text { Fluence } \\
\left(\mathrm{J} / \mathrm{cm}^{2}\right)\end{array}$ & $\begin{array}{l}\text { Time } \\
\text { (s) }\end{array}$ & $\begin{array}{c}\text { Power } \\
\text { Density } \\
\left(\mathrm{W} / \mathrm{cm}^{2}\right)\end{array}$ & $\begin{array}{l}\text { Cooling } \\
\text { (mL) }\end{array}$ \\
\hline G2 & Laser-in-Handpiece & contact & 100 & 30 & 3 & 0.8 & 19.89 & 60 & 593.7 & 30 \\
\hline G3 & Laser-in-Handpiece & contact & 200 & 30 & 6 & 0.8 & 39.79 & 60 & 1193,7 & 30 \\
\hline
\end{tabular}

The rest of the implants $(n=3)$, which were not inserted into the pig's bone, were used as a control in Scanning Electron Microscopy (SEM).

\subsection{Measurement Procedure}

The specimens were placed in a container with water at a room temperature of $22{ }^{\circ} \mathrm{C}$ for $20 \mathrm{~min}$; the temperature was monitored with a Medicare Clinical Products (MCP) Gold mercury thermometer (Medicare Products Inc., New Delhi, India). The temperature of the implant and abutment were measured employing a calibrated digital Thermometer CHY802W (CHY. Firemate Co., Tainan City, Taiwan) with the temperature probes of the K Thermocouple Probe, TP-02 type (Zhangzhou Weihua Electronic Co.). The measurement error was $0.3{ }^{\circ} \mathrm{C}$. A thermo-conductor paste ART covered the thermocouples.AGT-057 (AG Thermoplasty, Sokoly, Poland) to ensure proper thermal flow. The thermal conductivity of the paste was $0.243 \mathrm{Cal} / \mathrm{g} \mathrm{K}$. The temperature rise after $60 \mathrm{~s}$ of the laser irradiation, and scaling were recorded. Every measurement was taken three times, and the obtained mean subjected to 
statistical analysis. The maximum temperature was noted a few seconds after implant debridement for $60 \mathrm{~s}$ with laser or scalar when the temperature had reached a steady state.

\subsection{Scanning Electron Microscopy}

A total of 15 implants were assessed in SEM analysis. The implants were sputter-coated with approximately $30 \mathrm{~nm}$ gold. Scanning electron microscopy (SEM, acceleration $10 \mathrm{kV}$, Spot Size 40 and $50 \mathrm{~nm}$ ) evaluated the damage of the implant titanium surface. The analysis was conducted by a scanning electron microscope (JEOL6610LV, JEOL, Akishima, Japan) with a secondary emission detector (SEI, JEOL).

\subsection{Statistical Analysis}

The obtained outcomes were subjected to statistical analysis utilizing Statistica 12 (StatSoft ${ }^{\circledR}$, Tulsa, OK, USA) software. The mean increases in temperature of the implants and abutments have been assessed using the one-way ANOVA test. Pair comparisons were carried out based on the Tukey posthoc test at significance levels $p=0.05$.

\section{Results}

\subsection{Temperature Rise at Implant Level (P1 Thermocouple)}

The analysis of temperature rise, measured by a P1 thermocouple at the implant level, revealed a significantly lower temperature gradient for the each abutment type after irradiation using Er:YAG laser at $50 \mathrm{~mJ} / 30 \mathrm{~Hz}$, in contrast to Er:YAG laser at $100 \mathrm{~mJ} / 30 \mathrm{~Hz}$ and $200 \mathrm{~mJ} / 30 \mathrm{~Hz}(\mathrm{p}<0.0002)$. The highest mean temperature increases of $6.54 \pm 0.96{ }^{\circ} \mathrm{C}, 5.04 \pm 0.96{ }^{\circ} \mathrm{C}, 4.35 \pm 0.54{ }^{\circ} \mathrm{C}$ were found at $200 \mathrm{~mJ} / 30 \mathrm{~Hz}$ for two-piece implant abutment (IA), fix type fixture (FTF) and ball type fixture (BTF), respectively $(\mathrm{p}<0.05)$.

Furthermore, the temperature increases measured by P1 thermocouple after laser irradiation were higher at IA's connection type when compared with FTF and BTF $(\mathrm{p}<0.05)$.

However, for the scaler, we obtained significantly greater temperature increases at the BTF in comparison with FTF and IA. $(\mathrm{p}<0.05)$ (Table 2)

Table 2. The mean temperature gradient at implant level ( $\mathrm{P} 1$ thermocouple). The temperature rose significantly with an increased laser fluence. $(\mathrm{p}<0.0003)$ The temperature rise measured at the implant level after laser irradiation was higher at IA's connection type, in contrast to FTF and BTF. ( $\mathrm{p}<0.05)$.

\begin{tabular}{|c|c|c|c|c|}
\hline Study Groups & $\begin{array}{c}\text { Thermocouple } \\
\text { P1 } \Delta \text { Ta }\left({ }^{\circ} \text { C) IA (I) }\right. \\
\text { (Mean } \pm \text { SD) }\end{array}$ & $\begin{array}{l}\text { Thermocouple } \\
\text { P1 } 1 \Delta a\left({ }^{\circ} \mathrm{C}\right) \text { FTF }(\mathrm{I}) \\
(\text { Mean } \pm \text { SD) }\end{array}$ & $\begin{array}{l}\text { Thermocouple P1 } \Delta \text { Ta } \\
\left({ }^{\circ} \text { C) BTF (I) }\right. \\
\text { (Mean } \pm \text { SD) }\end{array}$ & P Value \\
\hline Group 1 & $1.55 \pm 0.55$ & $1.07 \pm 0.27^{+}$ & $0.86 \pm 0.46^{*+}$ & $\begin{array}{c}\text { IA vs. FTF, BTF } \mathrm{p}<0.05 \\
\text { FTF vs. BTF } \mathrm{p}>0.05\end{array}$ \\
\hline Group 2 & $3.62 \pm 0.74^{*}$ & $4.42 \pm 0.38$ * & $2.37 \pm 1.37^{+}$ & $\begin{array}{c}\text { IA, FTF vs. BTF } p<0.01 \\
\text { IA vs. FTF } p>0.05\end{array}$ \\
\hline Group 3 & $6.54 \pm 0.96^{*}$ & $5.04 \pm 0.96^{*+}$ & $4.35 \pm 0.54^{*+}$ & $\begin{array}{c}\text { IA vs. FTF, BTF } \\
p<0.0004 \\
\text { FTF vs. BTF } p>0.05\end{array}$ \\
\hline Group 4 & $1.15 \pm 0.54$ & $1.57 \pm 0.27^{+}$ & $2.43 \pm 0.23^{+}$ & $\begin{array}{c}\text { IA vs. FTF vs. BTF } \\
\mathrm{p}<0.05\end{array}$ \\
\hline$P$ value & $\begin{array}{c}\text { G1 vs. G2, G3 } \\
p<0.0002 \\
\text { G4 vs. G2, G3 } \\
p<0.0002 \\
\text { G1 vs.G4 } p>0.05\end{array}$ & $\begin{array}{c}\text { G1 vs. G2, G3 } \\
p<0.0002 \\
\text { G4 vs. G2, G3 } p<0.05 \\
\text { G1 vs. G4 } p>0.05\end{array}$ & $\begin{array}{c}\text { G1 vs. G2, G3, G4 } \\
p<0.0003 \\
\text { G2 vs. G3 } p<0.0002 \\
\text { G3 vs. G4 } p<0.0002 \\
\text { G2 vs. G4 } p>0.05\end{array}$ & \\
\hline
\end{tabular}

${ }^{*}$ Indicate significant differences between laser and control group G4 (ultrasonic scaler); ${ }^{+}$Indicate significant differences between the two-piece implant (IA) and one-piece implants (FTF, BTF). 


\subsection{Temperature Rise at Abutment/Implant Level (P2 Thermocouple)}

The analysis of temperature increase, measured by a P2 thermocouple at the abutment level, revealed a significantly lower temperature gradient for the two-piece implant (IA) after irradiation using Er:YAG laser at $50 \mathrm{~mJ} / 30 \mathrm{~Hz}$, as compared with Er:YAG laser at $100 \mathrm{~mJ} / 30 \mathrm{~Hz}$ and $200 \mathrm{~mJ} / 30 \mathrm{~Hz}$ $(\mathrm{p}<0.002)$. However, for the scaler at FTF (G4), the temperature increase was significantly lower in contrast to laser irradiation (G1, G2, G3) ( $<<0.0002)$.

The highest mean temperature rises of $5.86 \pm 0.46,7.62 \pm 0.74,10.67 \pm 1.14$ were found at 200 $\mathrm{mJ} / 30 \mathrm{~Hz}$ for two-piece implant (IA), FTF and BTF, respectively $(\mathrm{p}<0.0002)$.

The temperature rises in the G3 and G4 groups, measured by P2 thermocouple, were higher at BTF when compared with FTF and IA connection types $(\mathrm{p}<0.05)$. However, in the G1 and G2 groups the highest temperature increase measured using the P2 thermocouple was noted for the FTF in comparison with IA (G3) and BTF (G4) (p < 0.05) (Table 3).

Table 3. The mean temperature gradient at abutment level (P2 thermocouple). The temperature rose significantly with an increased laser fluence. $(\mathrm{p}<0.0003)$. The temperature rise by the critical $10{ }^{\circ} \mathrm{C}$ $\left(10.67+1.14{ }^{\circ} \mathrm{C}\right)$ was noted only for the ball type fixture (BTF) at $200 \mathrm{~mJ} / 30 \mathrm{~Hz}$. The temperature increase was significantly lower for the scaler (G4) in contrast to Er:YAG laser at FTF. $(\mathrm{p}<0.0002)$.

\begin{tabular}{|c|c|c|c|c|}
\hline Study Groups & $\begin{array}{l}\text { Thermocouple } \\
\text { P2 } \Delta \text { Ta }\left({ }^{\circ} \text { C) IA (A) }\right. \\
\text { (Mean } \pm \text { SD) }\end{array}$ & $\begin{array}{c}\text { Thermocouple } \\
\text { P2 } \Delta \text { Ta }\left({ }^{\circ} \text { C) FTF (A) }\right. \\
\text { (Mean } \pm \text { SD) }\end{array}$ & $\begin{array}{c}\text { Thermocouple } \\
\text { P2 } \Delta \mathrm{Ta}\left({ }^{\circ} \mathrm{C}\right) \text { BTF (A) } \\
\text { (Mean } \pm \text { SD) }\end{array}$ & P Value \\
\hline Group 1 & $0.95 \pm 0.55 *$ & $3.47 \pm 0.27^{*+}$ & $2.40 \pm 0.35^{+}$ & $\begin{array}{c}\text { IA vs. FTF vs. BTF } \\
p<0.05\end{array}$ \\
\hline Group 2 & $2.55 \pm 0.58$ & $5.50 \pm 0.89 *+$ & $3.12 \pm 0.74^{+}$ & $\begin{array}{c}\text { FTF vs. IA, BTF } \\
p<0.0002 \\
\text { FTF vs. BTF } \\
p<0.0002\end{array}$ \\
\hline Group 3 & $5.86 \pm 0.46^{*}$ & $7.62 \pm 0.74^{*+}$ & $10.67 \pm 1.14^{*+}$ & $\begin{array}{c}\text { IA vs. FTF vs. BTF } \\
\text { p }<0.05\end{array}$ \\
\hline Group 4 & $2.00 \pm 0.89$ & $2.13 \pm 0.23$ & $2.97 \pm 0.27^{+}$ & $\begin{array}{c}\text { BTF vs. IA, FTF } \\
p<0.003 \\
\text { FTF vs. BTF } p<0.003 \\
\text { IA vs. FTF } p>0.05\end{array}$ \\
\hline$P$ value & $\begin{array}{c}\text { G1 vs. G2, G3, G4 } \\
p<0.002 \\
\text { G2 vs. G3 } p<0.0002 \\
\text { G3 vs. G4 } p<0.0002 \\
\text { G2 vs. G4 } p>0.05\end{array}$ & $\begin{array}{l}\text { G1 vs. G2 vs. G3 vs. } \\
\text { G4 } p<0.0002\end{array}$ & $\begin{array}{c}\text { G3 vs. G2, G4 } \\
p<0.0002 \\
\text { G1 vs. G3 } p<0.0002 \\
\text { G1 vs. G2, G4 } p>0.05 \\
\text { G2 vs. G4 } p>0.05\end{array}$ & \\
\hline
\end{tabular}

${ }^{*}$ Indicates significant differences between laser and control group G4 (ultrasonic scaler); ${ }^{+}$Indicates significant differences between the two-piece implant (IA) and one-piece implants (FTF, BTF).

The analysis showed that, after $60 \mathrm{~s}$ of flapless debridement with Er:YAG at $200 \mathrm{~mJ} / 30 \mathrm{~Hz}$, the temperature increase by the critical $10^{\circ} \mathrm{C}\left(10.67 \pm 1.14^{\circ} \mathrm{C}\right)$ was noted for the ball type fixture (BTF) of the one-piece implant at the abutment level (P2 thermocouple). However, the highest mean temperature growth $\left(6.54 \pm 0.96^{\circ} \mathrm{C}\right)$ measured by the $\mathrm{P} 1$ thermocouple at the mid-side of the two-piece implant was below $10^{\circ} \mathrm{C}$ (Figure 4). 


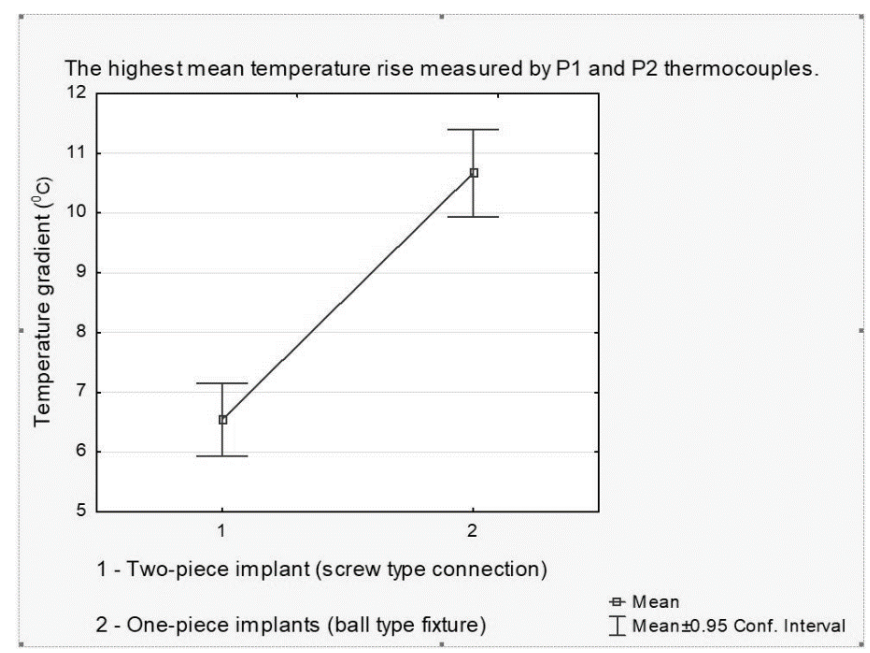

Figure 4. The highest mean temperature rise measured by P1 (at implant's level) and P2 (at abutment's level) thermocouples. The temperature rise by the critical $10{ }^{\circ} \mathrm{C}\left(10.67+1.14{ }^{\circ} \mathrm{C}\right)$ was noted for the ball type fixture (BTF) at the abutment level after lasing at $200 \mathrm{~mJ} / 30 \mathrm{~Hz}$ and was significantly higher compared with FTF and IA.

\subsection{SEM Analysis}

To test the damage to implants' titanium surface, SEM analysis was conducted. The main finding was that all samples debrided with the Er:YAG laser and the scaler showed minor damage (scratches, cracks) on the titanium surface of various implants. However, less damage was found when debriding one-piece implants with the scaler. Two-piece implants seem to be more sensitive to scratches during contact flapless debridement for all methods/devices (Figure 5). Furthermore, noticeable damage (cracks, melting) to the titanium surface of two-piece implants cleaned with the Er:YAG laser at 100 or $200 \mathrm{~mJ}$ was observed. Also, the specimens treated with the ultrasonic scaler with a plastic curette showed the remaining dark debris on the titanium surface (Figure 6).

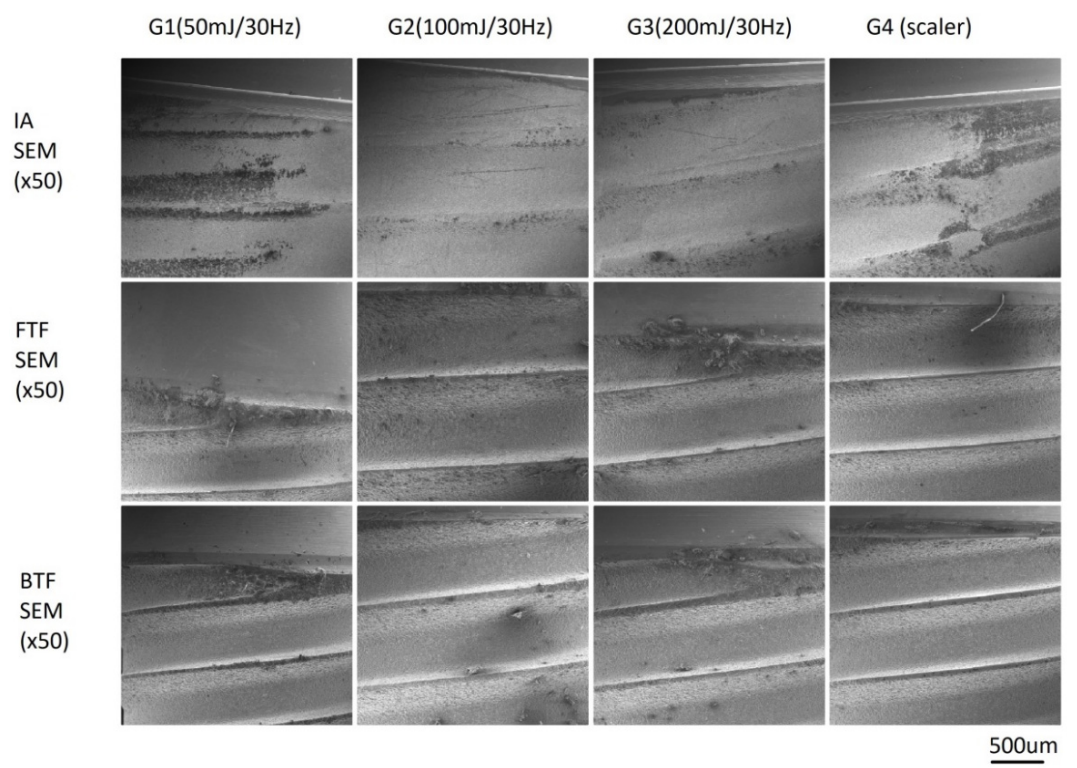

Figure 5. Damage to the SLA surface of implant treating by laser with different parameters (G1, G2, G3) and a scaler (G4) in contact mode. Scanning Electron Microscopy (SEM) $\times 50$. The minor damage (scratches, cracks) on the surface of titanium implants was found after debridement with both Er:YAG laser and scaler for all groups. However, less was found for the scaler on the one-piece implants with ball type fixture. 


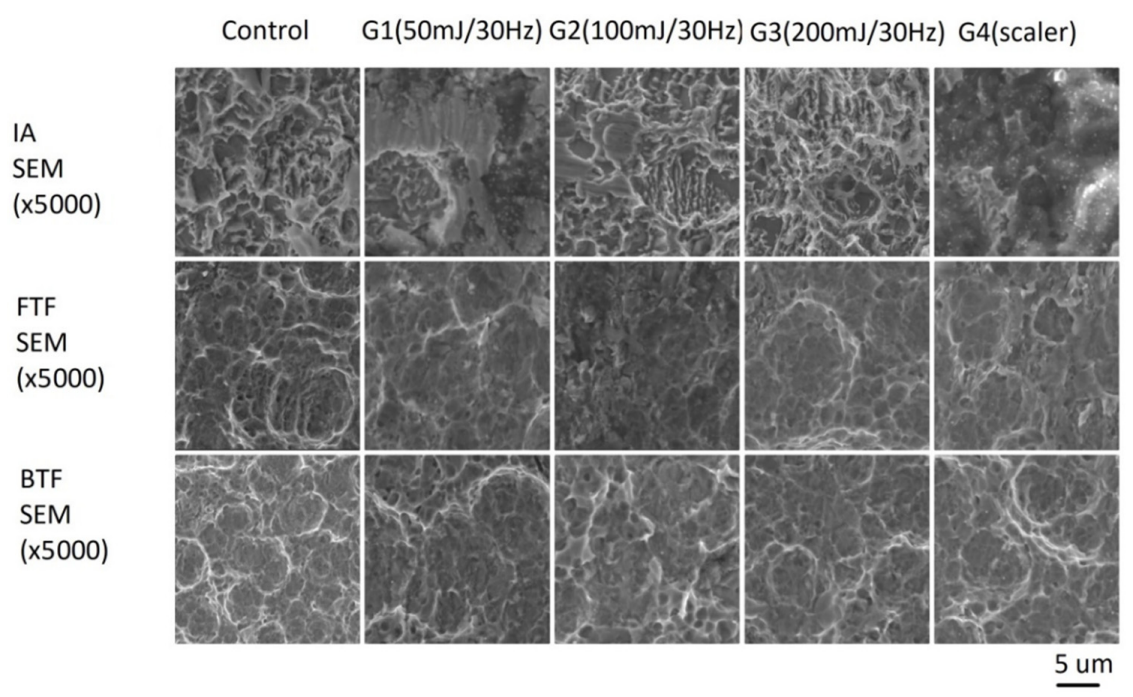

Figure 6. Damage to the SLA surface of implant treating by laser with different parameters (G1, G2, G3) and a scaler (G4) in contact mode. SEM $\times 5000$. Noticeable damage (cracks, melting) to the titanium surface of two-piece implants cleaned with Er:YAG laser at 100 or $200 \mathrm{~mJ}$ was observed. Also, the specimens treated with the ultrasonic scaler with plastic curette showed the remaining dark debris on the titanium surface.

\section{Discussion}

The application of lasers for dental implants' debridement has been investigated with regard to different wavelengths and protocols $[18,29,30,36]$. The present study contributes to the existing knowledge by testing the use of an Er:YAG laser operating in contact mode and an ultrasonic scaler with a plastic tip in a flapless debridement of one-piece and two-piece four grade titanium implants. The main finding of the present study was that Er:YAG laser at indicated parameters $(100 \mathrm{~mJ} / 30 \mathrm{~Hz}$ and $50 \mathrm{~mJ} / 30 \mathrm{~Hz}$ ) supports debridement of two-piece and one-piece implants with temperature rise at collar and at a mid-high level of implants below the critical $10^{\circ} \mathrm{C}$. Furthermore, the SEM analysis of each sample debrided by the Er:YAG laser and scaler indicated minor damage (melting, cracks) to the implants titanium surface.

The prime aim of the present study was to evaluate the temperature gradient at mid-height of implants during their debridement using various devices and treatment protocols. In our study we obtained the highest mean temperature increases measured at implant levels of $6.54 \pm 0.96{ }^{\circ} \mathrm{C}$, $5.04 \pm 0.96{ }^{\circ} \mathrm{C}, 4.35 \pm 0.54{ }^{\circ} \mathrm{C}$ at $200 \mathrm{~mJ} / 30 \mathrm{~Hz} / 60 \mathrm{~s}$ for a two-piece implant with a standard abutment (IA), fix type fixture (FTF) or ball type fixture (BTF), respectively. The results of the present study were below the critical temperature growth by $10{ }^{\circ} \mathrm{C}$, which causes irreversible damage to the peri-implant bone [34,35]. In 2002, Kreisler et al. [37,38] investigated temperature changes at the implant-bone interface during simulated implant surface decontamination with Er:YAG laser (pulse energy: $60-120 \mathrm{~mJ}, 10 \mathrm{~Hz}, 0.6-1.2 \mathrm{~W}$ ). They concluded that the temperature has not increased by $10^{\circ} \mathrm{C}$ after $120 \mathrm{~s}$ of irradiation, which also confirmed the safeness of the laser device. The efficiency of Er:YAG laser was also confirmed by Taniguchi et al. [30], who presented its ability to remove calcified deposits from contaminated titanium microstructures without causing substantial thermal damage at pulse energies below $30 \mathrm{~mJ} /$ pulse $\left(10.6 \mathrm{~J} / \mathrm{cm}^{2} /\right.$ pulse $)$ and $30 \mathrm{~Hz}$ with water spray. In our study, we tried to establish the safe parameter for the Er:YAG laser operation without a significant increase in the implant temperature (above $10^{\circ} \mathrm{C}$ ), and found them to be $50 \mathrm{~mJ}(1.5 \mathrm{~W}), 100 \mathrm{~mJ}(3 \mathrm{~W}), 200 \mathrm{~mJ}(6 \mathrm{~W})$.

Different conclusions to ours have been presented by Geminiani et al. [39] and Leja et al. [40]. They concluded that Er:YAG lasers induced temperature growth above the critical threshold of $10^{\circ} \mathrm{C}$ only after $10 \mathrm{~s}$ of irradiation. It should be emphasized that the study conducted by Lejla et al. [40] compared the temperature rise of the implants placed in pig ribs after lasing with air or air/water cooling, respectively. Unfortunately, the authors have not described the cooling parameters in detail $(\mathrm{mL} / \mathrm{min})$. 
The authors also pointed out that the $250 \mathrm{~mJ}$ Er:YAG laser reached a calculated temperature of $31.4^{\circ} \mathrm{C}$ with air cooling, but only $4.4^{\circ} \mathrm{C}$ with air/water cooling [35]. Hence, we can readily perceive that the waterflow capacity has a crucial influence on the final temperature gradient of the irradiated implants.

The second issue discussed in the study was the assessment of temperature increase at the implant's collar during debridement of various abutments. In our present study, we found the temperature gradient over the critical threshold of $10^{\circ} \mathrm{C}\left(10.67+1.14{ }^{\circ} \mathrm{C}\right)$ during the debridement procedure only for the one-piece implant with BTF at $200 \mathrm{~mJ}$ and $30 \mathrm{~Hz}$. This result does not vary much from the critical threshold of $10^{\circ} \mathrm{C}$ indicated by Eriksson et al. [34,35] in their two studies in the rabbit model. In turn, the study of Trisi et al. [41] in a human model showed that low-density bone seems to be frailer to heat-induced damage than high-density bone. Consequently, temperature rises in the cortical bone or collar part of the implant (measured by P2 thermocouple) slightly higher than the critical threshold should not cause irreversible thermal damage. However, our present research was an ex vivo study with characteristic limitations, e.g., various chemical structures and the biological features of the ex vivo specimens in contrast to in vivo tissue, mainly due to the lack of blood circulation. Thus, our findings should also be confirmed in the human in vivo model and using the implants of various manufactures.

Furthermore, the mean temperature gradient was higher for the fix type fixture as compared with implant-abutment interphase of two-piece implants. The one-piece implants differ from the two-piece systems in their constant implant-abutment connection [42]. This fact could influence the heat dissipation around various abutments. The distribution of heat during laser irradiation depends on lasing device parameters, diameter, and grades of titanium implants, but also is conjugated with peri-implant bone density $[18,43-45]$. Therefore, taking into account the susceptibility of the crestal peri-implant bone to resorption, the use of a mean power below $6 \mathrm{~W}(200 \mathrm{~mJ} / 30 \mathrm{~Hz})$ or an increase in the water flow over $20 \mathrm{~mL} / \mathrm{min}$ is recommended to avoid the risk of thermal damage in this particular area.

Another goal of our study was to evaluate damage to the implant's surface using SEM analysis. We found laser debridement caused minor damage to the titanium structure of one-piece implants with BTF and FTF, based on SEM analysis, while pronounced cracks and melting occurred in two-piece implants. In our present study, we cleaned the surface of the implants by placing the tip of the Er:YAG laser and ultrasonic scaler below the soft tissue margin remaining in contact with the treated implants. In this procedure, we debrided the implant surface without an operators' sight control; this can lead to higher risk of damage to the titanium surface, due to the generation of high photomechanical effects between the titanium surface and a sapphire tip transporting energy to the target area. Moreover, in the literature, there are studies $[20,42,43]$ assessing the degree of damage in the implant titanium surface under the effect of scalers with a polymer coated tip. The main conclusion of these studies was that the polymer scalers are efficient in cleaning the titanium implant without any damage to its surface. In our study, we have shown that the ultrasounds caused damage to two-piece implants microstructure and evoked the implants' surface darkening. The possible explanation of the dark debris covering the surface of the implant is a remaining material which was split from a plastic tip after the treatment. Taniguchi and colleges [30] also confirmed this finding.

A particular focus in the present research was to assess the Er:YAG laser effects during debridement of the implant-abutment interface as a non-surgical therapy of peri-implantitis. Several previous reports have confirmed a high decontamination potential of lasers in vitro and in vivo studies [36,45-50]. However, the various laser parameters and protocols used in different studies did not enable the finding of clear and safe recommendations in the non-surgical treatment of peri-implantitis employing Er:YAG laser [51]. The high decontamination potential of Er:YAG laser in infected titanium implants was found at parameters of $100 \mathrm{~mJ} /$ pulse, $10 \mathrm{~Hz}\left(=12.7 \mathrm{~J} / \mathrm{cm}^{2}\right)$ [45]. The efficiency of peri-implantitis treatment was also confirmed for Er:YAG laser at $100 \mathrm{~mJ} / \mathrm{pulse}, 10 \mathrm{~Hz}$ with water cooling by a significant improvement of the clinical parameters, e.g., $\mathrm{BOP}=$ bleeding on probing, $\mathrm{CAL}=$ clinical attachment level, $\mathrm{PD}=$ probing depth in 6-month follow-up [36]. Furthermore, Sennhenn-Kirchner et al. [47] 
reported a nearly complete removal of fungal cells with Er:YAG laser using the same laser parameters $(100 \mathrm{~mJ} /$ pulse $10 \mathrm{~Hz})$.

Both decontamination potential and irrigation efficiency are important during peri-implantitis therapy. Many authors confirmed the ability of Er:YAG laser to remove bacterial biofilm and decontamination of titanium surface at $60-100 \mathrm{~mJ} / 10 \mathrm{~Hz}[30,38,45]$. However, the removal of inflamed tissues from peri-implant pocket using Er:YAG laser by debridement of the implant and abutment surfaces is crucial in determining a significant clinical benefit. To enhance the water irrigation pressure in a peri-implant pocket, the ratio of pulse energy and frequency is critical. In a different study, we recommended inducing water irrigation following the photoacoustic phenomena by the use of the energy/frequency ratio of $50 \mathrm{~mJ} / 50 \mathrm{~Hz}$ [52]. The erbium laser used in this study allowed the induction of visible water agitation by photoacoustic effect at $100 \mathrm{~mJ} / 30 \mathrm{~Hz}$, without the temperature rise by $10^{\circ} \mathrm{C}$ for all abutment types. This energy also is sufficient for bacterial biofilm removal. Hence, in our opinion, the use of the Er:YAG laser at $100 \mathrm{~mJ} / 30 \mathrm{~Hz}$ in debridement of peri-implant pocket could be safe and efficient.

All these facts make variable decontamination protocols necessary. Therefore, it is even more important to know the effects of laser irradiation on the implant surface, and the temperature increases of different implant types and materials which are safe for clinical use. The various possible settings of Er:YAG laser, enables effective treatment of peri-implantitis, but further studies are needed to better understand its thermal impact on both the intraosseous components and prosthetic superstructures.

\section{Conclusions}

The result of this study can be summarized as follows:

- The Er:YAG laser debridement of two-piece and one-piece implants did not exceed the implant temperature by $10^{\circ} \mathrm{C}$ at $100 \mathrm{~mJ} / 30 \mathrm{~Hz}$ and $50 \mathrm{~mJ} / 30 \mathrm{~Hz}$;

- One-piece implants heat up faster than two-piece implants during Er:YAG laser irradiation at the implant's collar area;

- Based on SEM analysis, the cracks and melting that occurred on the surface of two-piece implants were more pronounced compared to one-piece implants with the ball type fixture (BTF) and fix type fixture (FTF);

- Debridement of one-piece implants with a ball type fixture using Er:YAG laser at $200 \mathrm{~mJ} / 30 \mathrm{~Hz}$ or more should be avoided. However, our findings should also be confirmed in the human in vivo model and using the implants of various manufactures.

We recommend using the Er:YAG laser with an energy/frequency ratio of $50 \mathrm{~mJ} / 30 \mathrm{~Hz}$ during non-surgical therapy of peri-implantitis.

Author Contributions: Conceptualization, J.M. and U.R.; methodology, J.M.; investigation, J.M. and K.M.; writing—original draft preparation, J.M. and U.R.; writing—review and editing, K.G.-L. and U.R.; supervision, M.D.

Funding: This research received no external funding.

Conflicts of Interest: The authors declare no conflict of interest.

\section{References}

1. Matys, J.; Swider, K.; Flieger, R. Laser instant implant impression method: A case presentation. Dent. Med. Probl. 2017, 54, 101-106. [CrossRef]

2. Atieh, M.A.; Alsabeeha, N.H.; Faggion, C.M., Jr.; Duncan, W.J. The frequency of peri-implant diseases: A systematic review and meta-analysis. J. Periodontol. 2013, 84, 1586-1598. [CrossRef] [PubMed]

3. Świder, K.; Dominiak, M.; Grzech-Leśniak, K.; Matys, J. Effect of Different Laser Wavelengths on Periodontopathogens in Peri-Implantitis: A Review of In Vivo Studies. Microorganisms 2019, 7, 189. [CrossRef] [PubMed] 
4. Lindhe, J.; Meyle, J. Peri-implant diseases: Consensus Report of the Sixth European Workshop on Periodontology. J. Clin. Periodontol. 2008, 35, 282-285. [CrossRef] [PubMed]

5. Boever, A.L.; Boever, J.A. Early colonization of non-submerged dental implants in patients with a history of advanced aggressive periodontitis. Clin. Oral Implants Res. 2006, 17, 8-17. [CrossRef] [PubMed]

6. Fürst, M.M.; Salvi, G.E.; Lang, N.P.; Persson, G.R. Bacterial colonization immediately after installation on oral titanium implants. Clin. Oral Implants Res. 2007, 18, 501-508. [CrossRef] [PubMed]

7. Leonhardt, Å.; Renvert, S.; Dahlén, G. Microbial findings at failing implants. Clin. Oral Implants Res. 1999, 10, 339-345. [CrossRef]

8. Bassi, F.; Poli, P.P.; Rancitelli, D.; Signorino, F.; Maiorana, C. Surgical treatment of peri-implantitis: A 17-year follow-up clinical case report. Case Rep. Dent. 2015, 2015, 574676. [CrossRef]

9. Aljateeli, M.; Fu, J.H.; Wang, H.L. Managing Peri-Implant Bone Loss: Current Understanding. Clin. Implant Dent. Relat. Res. 2012, 14, e109-e118. [CrossRef]

10. Schwarz, F.; Sahm, N.; Bieling, K.; Becker, J. Surgical regenerative treatment of peri-implantitis lesions using a nanocrystalline hydroxyapatite or a natural bone mineral in combination with a collagen membrane: A four-year clinical follow-up report. J. Clin. Periodontol. 2009, 36, 807-814. [CrossRef]

11. Claffey, N.; Clarke, E.; Polyzois, I.; Renvert, S. Surgical treatment of peri-implantitis. J. Clin. Periodontol. 2008, 35, 316-332. [CrossRef] [PubMed]

12. Augthun, M.; Tinschert, J.; Huber, A. In vitro studies on the effect of cleaning methods on different implant surfaces. J. Periodontol. 1998, 69, 857-864. [CrossRef] [PubMed]

13. Louropoulou, A.; Slot, D.E.; Van der Weijden, F.A. Titanium surface alterations following the use of different mechanical instruments: A systematic review. Clin. Oral Implants Res. 2012, 23, 643-658. [CrossRef] [PubMed]

14. Schwarz, F.; Ferrari, D.; Popovski, K.; Hartig, B.; Becker, J. Influence of different air-abrasive powders on cell viability at biologically contaminated titanium dental implants surfaces. J. Biomed. Mater. Res. B Appl. Biomater. 2009, 88, 83-91. [CrossRef]

15. Tastepe, C.S.; van Waas, R.; Liu, Y.; Wismeijer, D. Air powder abrasive treatment as an implant surface cleaning method: A literature review. Int. J. Oral Maxillofac. Implants 2012, 27, 1461-1473.

16. Bergendal, T.; Forsgren, L.; Kvint, S.; Löwstedt, E. The effect of an airbrasive instrument on soft and hard tissues around osseointegrated implants. A case report. Swed. Dent. J. 1989, 14, 219-223.

17. Mengel, R.; Buns, C.-E.; Mengel, C.; Flores-de-Jacoby, L. An in vitro study of the treatment of implant surfaces with different instruments. Int. J. Oral Maxillofac. Implants 1998, 13, 91-96.

18. Matys, J.; Botzenhart, U.; Gedrange, T.; Dominiak, M. Thermodynamic effects after Diode and Er: YAG laser irradiation of grade IV and V titanium implants placed in bone-an ex vivo study. Preliminary report. Biomed. Tech. (Berl.) 2016, 61, 499-507. [CrossRef]

19. Park, J.B.; Jang, Y.J.; Koh, M.; Choi, B.K.; Kim, K.K.; Ko, Y. In vitro analysis of the efficacy of ultrasonic scalers and a toothbrush for removing bacteria from resorbable blast material titanium disks. J. Periodontol. 2013, 84, 1191-1198. [CrossRef]

20. Rühling, A.; Kocher, T.; Kreusch, J.; Plagmann, H.C. Treatment of subgingival implant surfaces with Teflon ${ }^{\circledR}$-coated sonic and ultrasonic scaler tips and various implant curettes. An in vitro study. Clin. Oral Implants Res. 1994, 5, 19-29. [CrossRef]

21. Wilson, V. An insight into peri-implantitis: A systematic literature review. Prim. Dent. Care 2013, 2, 69-73. [CrossRef] [PubMed]

22. Koka, S.; Han, J.; Razzoog, M.E.; Bloem, T.J. The effects of two air-powder abrasive prophylaxis systems on the surface of machined titanium: A pilot study. Implant Dent. 1992, 1, 259-265. [CrossRef] [PubMed]

23. McCollum, J.; O’Neal, R.B.; Brennan, W.A.; Van Dyke, T.E.; Horner, J.A. The effect of titanium implant abutment surface irregularities on plaque accumulation in vivo. J. Periodontol. 1992, 63, 802-805. [CrossRef] [PubMed]

24. Zablotsky, M.H.; Wittrig, E.E.; Diedrich, D.L.; Layman, D.L.; Meffert, R. MFibroblastic growth and attachment on hydroxyapatite-coated titanium surfaces following the use of various detoxification modalities. Part II: Contaminated hydroxyapatite. Implant Dent. 1992, 1, 195-202. [CrossRef] [PubMed]

25. Grzech-Leśniak, K.; Matys, J.; Jurczyszyn, K.; Ziółkowski, P.; Dominiak, M.; Brugnera, A.J., Jr.; Romeo, U. Histological and Thermometric Examination of Soft Tissue De-Epithelialization Using Digitally Controlled Er:YAG Laser Handpiece: An Ex Vivo Study. Photomed. Laser Surg. 2018, 36, 313-319. [CrossRef] [PubMed] 
26. Romeo, U.; Russo, C.; Palaia, G.; Lo Giudice, R.; Del Vecchio, A.; Visca, P.; Migliau, G.; De Biase, A. Biopsy of different oral soft tissues lesions by KTP and diode laser: Histological evaluation. TSWJ 2014, 2014, 761704. [CrossRef]

27. Romeo, U.; Del Vecchio, A.; Palata, G.; Tenore, G.; Visca, P.; Maggiore, C. Bone damage induced by different cutting instruments: An in vitro study. Braz. Dent. J. 2009, 20, 162-168. [CrossRef]

28. Matys, J.; Flieger, R.; Tenore, G.; Grzech-Leśniak, K.; Romeo, U.; Dominiak, M. Er: YAG laser, piezosurgery, and surgical drill for bone decortication during orthodontic mini-implant insertion: Primary stability analysis-An animal study. Lasers Med. Sci. 2018, 33, 489-495. [CrossRef]

29. Valderrama, P.; Wilson, T.G., Jr. Detoxification of implant surfaces affected by peri-implant disease: An overview of surgical methods. Int. J. Dent. 2013, 2013, 749680. [CrossRef]

30. Taniguchi, Y.; Aoki, A.; Mizutani, K. Optimal Er: YAG laser irradiation parameters for debridement of microstructured fixture surfaces of titanium dental implants. Lasers Med. Sci. 2013, 28, 1057-1068. [CrossRef]

31. Takasaki, A.A.; Aoki, A.; Mizutani, K.; Kikuchi, S.; Oda, S.; Ishikawa, I. Er: YAG laser therapy for peri-implant infection: A histological study. Lasers Med. Sci. 2007, 22, 143-157. [CrossRef] [PubMed]

32. Schwarz, F.; Bieling, K.; Nuesry, E.; Sculean, A.; Becker, J. Clinical and histological healing pattern of peri-implantitis lesions following non-surgical treatment with an Er: YAG laser. Lasers Surg. Med. 2006, 38, 663-671. [CrossRef] [PubMed]

33. Heinemann, F.; Hasan, I.; Kunert-Keil, C.; Götz, W.; Gedrange, T.; Spassov, A.; Schweppe, J.; Gredes, T. Experimental and histological investigations of the bone using two different oscillating osteotomy techniques compared with conventional rotary osteotomy. Ann. Anat. Anat. Anz. 2012, 194, 165-170. [CrossRef] [PubMed]

34. Eriksson, A.R.; Albrektsson, T. Temperature threshold levels for heat-induced bone tissue injury: A vital-microscopic study in the rabbit. J. Prosthet. Dent. 1983, 50, 101-107. [CrossRef]

35. Eriksson, A.R.; Albrektsson, T.; Magnusson, B. Assessment of bone viability after heat trauma. A histological, histochmeical and vital microscopic study in the rabbit. Scand. J. Plast. Reconstr. Surg. 1984, 18, 261-268. [CrossRef] [PubMed]

36. Schwarz, F.; Sculean, A.; Rothamel, D.; Schwenzer, K.; Georg, T.; Becker, J. Clinical evaluation of an Er:YAG laser for nonsurgical treatment of peri-implantitis: A pilot study. Clin. Oral Implants Res. 2005, 16, 44-52. [CrossRef]

37. Kreisler, M.; Al Haj, H.; d'Hoedt, B. Temperature changes at the implant-bone interface during simulated surface decontamination with an Er: YAG laser. Int. J. Prosthodont. 2002, 15, 582-587.

38. Kreisler, M.; Kohnen, W.; Marinello, C.; Götz, H.; Duschner, H.; Jansen, B.; d'Hoedt, B. Bactericidal effect of the Er: YAG laser on dental implant surfaces: An in vitro study. J. Periodontol. 2002, 73, 1292-1298. [CrossRef]

39. Geminiani, A.; Caton, J.G.; Romanos, G.E. Temperature increase during CO2 and Er: YAG irradiation on implant surfaces. Implant Dent. 2011, 20, 379-382. [CrossRef]

40. Leja, C.; Geminiani, A.; Caton, J.; Romanos, G.E. Thermodynamic effects of laser irradiation of implants placed in bone: An in vitro study. Lasers Med. Sci. 2013, 28, 1435-1440. [CrossRef]

41. Trisi, P.; Berardini, M.; Falco, A.; Vulpiani, M.P. Effect of Temperature on the Dental Implant Osseointegration Development in Low-Density Bone: An In Vivo Histological Evaluation. Implant Dent. 2015, 24, 96-100. [CrossRef]

42. Cohen, O.; Gabay, E.; Machtei, E.E. Cooling profile following prosthetic preparation of 1-piece dental implants. J. Oral Implantol. 2010, 36, 273-279. [CrossRef] [PubMed]

43. Matys, J.; Flieger, R.; Dominiak, M. Assessment of Temperature Rise and Time of Alveolar Ridge Splitting by Means of Er:YAG Laser, Piezosurgery, and Surgical Saw: An Ex Vivo Study. BioMed Res. Int. 2016, 2016, 9654975. [CrossRef]

44. Matys, J.; Dominiak, M.; Flieger, R. Energy and Power Density: A Key Factor in Lasers Studies. J. Clin. Diagn. Res. 2015, 9, ZL01-ZL02. [CrossRef] [PubMed]

45. Schwarz, F.; Rothamel, D.; Sculean, A.; Georg, T.; Scherbaum, W.; Becker, J. Effects of an Er:YAG laser and the Vector ultrasonic system on the biocompatibility of titanium implants in cultures of human osteoblast-like cells. Clin. Oral Implants Res. 2003, 14, 784-792. [CrossRef]

46. Schwarz, F.; Sculean, A.; Romanos, G.; Herten, M.; Horn, N.; Scherbaum, W.; Becker, J. Influence of different treatment approaches on the removal of early plaque biofilms and the viability of SAOS2 osteoblasts grown on titanium implants. Clin. Oral Investig. 2005, 9, 111-117. [CrossRef] [PubMed] 
47. Sennhenn-Kirchner, S.; Schwarz, P.; Schliephake, H.; Konietschke, F.; Brunner, E.; Borg-von Zepelin, M. Decontamination efficacy of erbium:yttrium-aluminium-garnet and diode laser light on oral Candida albicans isolates of a 5-day in vitro biofilm model. Lasers Med. Sci. 2009, 24, 313-320. [CrossRef] [PubMed]

48. Sennhenn-Kirchner, S.; Klaue, S.; Wolff, N.; Mergeryan, H.; Borg von Zepelin, M.; Jacobs, H.G. Decontamination of rough titanium surfaces with diode lasers: Microbiological findings on in vivo grown biofilms. Clin. Oral Implants Res. 2007, 18, 126-132. [CrossRef] [PubMed]

49. Fontana, C.R.; Kurachi, C.; Mendonca, C.R.; Bagnato, V.S. Microbial reduction in periodontal pockets under exposition of a medium power diode laser: An experimental study in rats. Lasers Surg. Med. 2004, 35, 263-268. [CrossRef]

50. Monzavi, A.; Shahabi, S.; Fekrazad, R.; Behruzi, R.; Chiniforush, N. Implant surface temperature changes during Er: YAG laser irradiation with different cooling systems. J. Dent. (Tehran) 2014, 11, 210-215.

51. Kamel, M.S.; Khosa, A.; Tawse-Smith, A.; Leichter, J. The use of laser therapy for dental implant surface decontamination: A narrative review of in vitro studies. Lasers Med. Sci. 2014, 29, 1977-1985. [CrossRef] [PubMed]

52. Matys, J.; Hadzik, J.; Dominiak, M. Schneiderian Membrane Perforation Rate and Increase in Bone Temperature During Maxillary Sinus Floor Elevation by Means of Er: YAG Laser-An Animal Study in Pigs. Implant Dent. 2017, 26, 238-244. [CrossRef] [PubMed]

(C) 2019 by the authors. Licensee MDPI, Basel, Switzerland. This article is an open access article distributed under the terms and conditions of the Creative Commons Attribution (CC BY) license (http://creativecommons.org/licenses/by/4.0/). 